have seen the beginning of exact description in terms of organic and physical chemistry. In the last few years a whole series of hormones has been isolated chemically and several synthesized. Four or five vitamins have been identified chemically and at least three synthesized. Sex hormones, one vitamin, carcinogenic substances and heart tonics have been chemically related to the typically inert sterols. Already new substances have been synthesized which promise to give control over some of the most deadly infections of man, especially in the tropics. The whole orientation of therapeutics is being shifted from the effects to the causes of disease. Sir Henry Dale suggested that the greatest service of chemistry to the community lies in this new and increasing domination of biological and medical research by chemical methods and ideas. In urging the necessity for co-operation between the chemist and those trained primarily in biology and the medical sciences, he protested strongly against the neglect in Great Britain of the study of tropical diseases. While we control more of the tropics than any other country in the world, we have done comparatively little in attacking the problems of tropical disease. It is unlikely that we shall be able to justify permanently the possession of large sections of the globe, and depend on the efforts of other nations to make them habitable.

\section{The Mediterranean Littoral}

$\mathrm{T}$

HE Consiglio Nazionale delle Ricerche has undertaken, through the agency of the National Committee for Geography in conjunction with the Institute of General Geography of the University of Pisa, an inquiry into recent conditions affecting sandy beaches along the Italian littoral, and in this connexion is publishing a series of monographs dealing with the coastline in ten regional sections, each of which is to form the subject of a separate volume. In this way, reviving the studies of eminent physiographers of the past, it is intended to present a ehain of facts which will serve for a systematic research into the regimen of Italian beaches and so foster the advancement of scientific geography, at the same time aiding in the development of maritime engineering.

The opening volume of the series, forming an introduction to the whole subject, has been prepared by Signor Agatino D'Arrigo*, an engineer of acknowledged competence and merit, who has received the distinction of the award of a premium from the Royal Academy of Italy for his publications on coastline phenomena. He has produced an excellent historical review of the subject, giving an account of the earlier investigations of Italian observers from Leonardo da Vinci, Montanari, Marsili and Paleocapa to Cialdi and Cornaglia, including at the same time appropriate references to the facts recorded by writers of other nationalities. The first part of the volume is taken up with this disquisition, and is followed by certain deductions of a general order to which limitations of space do not permit reference in detail.

The second part consists of a series of comparative morpholithological studies of the regimen of various parts of the Mediterranean littoral, including the Nile Delta, the Delta of the Po and the adjacent

* Ricerche sul Regime dei Litorali nel Mediterraneo. By Agatino D'Arrigo. Pp. 172. (Rome: Stabilimento Tipografico "Aternum".) 50 lire.
Venetian region, the Delta of the Rhone, the Delta of the Tiber, the Bay of Taormina, the Algerian Littoral and the Argentarian Promontory, with a final chapter embodying the conclusions of the author.

The investigations are obviously spread over a wide field and while they serve as an admirable introduction to a further and more complete survey, their immediate value is perhaps best assessed, as stated by Prof. Toniolo in his preface to the volume, as a general confirmation of the hypothesis already advanced of the probable reversibility of the cycle of evolution of the Mediterranean littoral. For physiographers of other nationalities, the book contains a great deal of serviceable information, with useful references to the work of Italian investigators. The treatise, in fact, is commendably documented, and there is an excellent set of coloured charts showing coastline changes at various dates. B. C.

\section{Educational Topics and Events}

Wild-Barfield Electric Furnaces, Ltd., Elecfurn Works, North Road, Holloway, London, N.7, have prepared a series of lantern slides illustrating many types of electric furnaces for heat-treatment, together with notes regarding the various slides. These form the basis of a paper on such equipment, and sets and lecture are available for societies, technical schools or other interested bodies.

Formax education for marriage is advocated by Paul H. Landis of the State College of Washington in an article on "Control of the Romantic Impulse through Education" published in School and Society of August 15. The mounting divorce rate in the United States, now higher than in any other country, is, he suggests, attributable in some measure to the frequency of romantic marriages, and of this the chief cause is the mobility characteristic of contemporary American life, especially in the West, where the divorce rate is highest. "In most fields now we believe in giving experience vicariously through books and the school curriculum, yet in the field of marriage and the family we let youth learn by experience." We need courses in high school and college in eugenies and the essentials of happy family life, to set up new barriers to the free exercise of the romantic urge.

The Education Act 1936 throws upon local education committees a heavy addition to their responsibilities. In persistently agitating for the raising of the obligatory school age, for which the new Act provides, they have, as an editorial in their official organ, Education, of September 4, points out, created for themselves a vast moral obligation. The issues involved in adjudicating upon applications for exemption closely concern the well-being of the community : the health and physical condition of the child; the 'beneficial' nature of the proposed employment, including its prospective benefit; the opportunities to be afforded of free education; the time available for recreation; and the case of each individual child will call for careful consideration. The grant of an employment certificate in respect of an exempted child is clearly intended to be a deliberate judicial act, not the routine application of a rough and ready test. An incidental advantag€ 
of this procedure will be that members of the com. mittees will be constantly face to face with the question-what is the content of this final year of compulsory schooling and what is its probable value in any particular case? It is, the article points out, in this connexion, that loyal and willing co-operation between the Board of Education, local authorities and teachers will be specially desirable. A series of articles by Dr. Percival Sharp, secretary of the Association of Education Committees, on the problems presented by the administration of the new Act, is promised.

The 'brain trust' in American politics is symptomatic of that pronounced swing towards the social sciences which has been one of the most noticeable features of university life in the United States in recent years. Commenting on this movement, the president of Yale University in an Alumni Day address urged the frank and definite recognition by universities of the "preponderant importance for our day and for the immediate future of the crucial problems of the industrial and economic order and of the individual human life in all its physical, social and spiritual aspects". Failing such recognition and energetic fulfilment of the universities' correlative obligations to the social order, they may have to face "the destruction of all that we and our predecessors have given our lives to create". But the "brain trust', in so far as it involves the exploitation of university faculties by Government departments, is obviously liable to abuse, and a public protest has, according to School and Society of July 25, been made by $\mathrm{Mr}$. Walter Lippmann and eight other prominent alumni of Harvard against the consequential neglect by professors of their academic duties. In Great Britain, on the other hand, one doubts whether Government departments make sufficient use of the brains of university staffs and advanced students. In the Ministry of Labour's report for 1935, for example, there is no evidence of contact between the Ministry and university departments concerned with cognate matters, although these doubtless study the masses of statistics provided by the Ministry.

The president of Columbia University, New York, Dr. Nicholas Murray Butler, in his recent "Commencement Day" address on "The Decline and Fall of Morals", quoted Thomas Jefferson's prophecy that the cult of the "almighty dollar" would lead to heavier and heavier shackling of the people's freedom "till our rights shall revive or expire in a convulsion" -an altermative which is, Dr. Butler declared, the one dominant question before the world to-day. With this question is also bound up the fate of morals, for the destruction of liberty would make morals impossible. He referred to the German people's once powerful influence in the intellectual and economic life of the world, forfeited for the time being under a self-confident tyranny that boasts (Dr. Goebbels, on March 19) "we do not have to appeal to the people, we have the army, the police, the wireless, the press, the Nazi organization". He noted the utter disregard by Japan and Italy of moral obligation and their recourse to mass murder, and the strange mutation of Mussolini's principles since 1913, when he rebuked his countrymen for the "stupid orgy . . . in which the Italian press is now letting itself go with mad exaltation. Strong peoples have some sense of measure. Italy, rationalist and militarist, shows that it lacks this sense . . a miserable war of conquest (the conquest of Tripoli) is acclaimed as if it were a Roman triumph." Another university president, Dr. Sproul of the University of California, speaking on June 30 on "America's Answer to Youth's Appeal", similarly stressed the preponderant importance for our day of safeguarding "freedom and tolerance, respect for the individual, regard for the rights of minorities. . .."

\section{Science News a Century Ago}

\section{J. D. Forbes and Auguste de la Rive}

ThE enthusiasm shown at the Bristol meeting of the British Association in the experiments of Andrew Crosse, referred to in NaTuRE last week, was not shared by J. D. Forbes, who shortly after returning from Bristol, on September 26, 1836, wrote to Auguste de la Rive: "The subject of Mr. Cross is, I confess, rather a disagreeable one to me. You will readily enough conceive how much people more conversant with geology than electricity must have been struck by hearing most eloquently expounded a series of experimental discoveries, for they were perfectly original to Mr. Cross, silently prosecuted for many years by a retired country gentleman in Somersetshire, and only elicited by chance in the course of discussion. From the first moment that the matter was mentioned to me, and on every succeeding occasion, I really believe not less than fifty times, I have patiently vindicated the claims of Becquerel, which only require to be mentioned to be acknow. ledged. I own I felt somewhat indignant on the subject, because having seen Becquerel's magnificent preparations and conversed at great length with him on the subject, I had been led at various times, publicly and privately, for several years, to draw the attention of geologists to one of the very best things ever done for their science. . . ."

\section{Medical Museum at King's College, London}

ON September 30, 1836, The Times said: "The Society of Apothecaries has lately enriched the various collections in the medical school [of King's College] by the presentation of a large and beautiful series of specimens of the materia medica, being duplicates of those selected from their own collections at Apothecaries-hall. As much care is required in choosing the purest and best specimens, many of which it requires time to procure, it is not expected the collection will be quite complete for many months. A new room has been opened in the college for their now extensive museum of materia medica. The dormitories for the students, fully furnished, and abundantly ventilated, a new medical reading room, as well as dining-hall or refectory, to be opened early in October, are among the newest improvements in the college."

\section{Sturgeon's Annals of Electricity}

Is October 1836 appeared the first number of the periodical "The Annals of Electricity, Magnetism, and Chemistry and Guardian of Experimental Science, conducted by William Sturgeon, Lecturer on Experimental Philosophy at the Honorable East India Company's Seminary, Addiscombe, etc., and assisted by gentlemen eminent in these departments of philosophy". The greater part of the number 